\title{
Novel insights into PARPs in gene expression: regulation of RNA metabolism
}

\author{
Yueshuang $\mathrm{Ke}^{1} \cdot$ Jing $\mathrm{Zhang}^{1} \cdot$ Xueping $\mathrm{Lv}^{1} \cdot$ Xianlu Zeng ${ }^{1} \cdot$ Xueqing $\mathrm{Ba}^{1,2}$
}

Received: 14 November 2018 / Revised: 13 April 2019 / Accepted: 29 April 2019 / Published online: 4 May 2019

(c) The Author(s) 2019

\begin{abstract}
Poly(ADP-ribosyl)ation (PARylation) is an important post-translational modification in which an ADP-ribose group is transferred to the target protein by poly(ADP-riboses) polymerases (PARPs). Since the discovery of poly-ADP-ribose (PAR) 50 years ago, its roles in cellular processes have been extensively explored. Although research initially focused on the functions of PAR and PARPs in DNA damage detection and repair, our understanding of the roles of PARPs in various nuclear and cytoplasmic processes, particularly in gene expression, has increased significantly. In this review, we discuss the current advances in understanding the roles of PARylation with a particular emphasis in gene expression through RNA biogenesis and processing. In addition to updating PARP's significance in transcriptional regulation, we specifically focus on how PARPs and PARylation affect gene expression, especially inflammation-related genes, at the post-transcriptional levels by modulating RNA processing and degrading. Increasing evidence suggests that PARP inhibition is a promising treatment for inflammation-related diseases besides conventional chemotherapy for cancer.
\end{abstract}

Keywords Poly ADP-ribosylation · PARP1 - Gene expression · Transcription · RNA metabolism · RNA-binding proteins · Inflammation

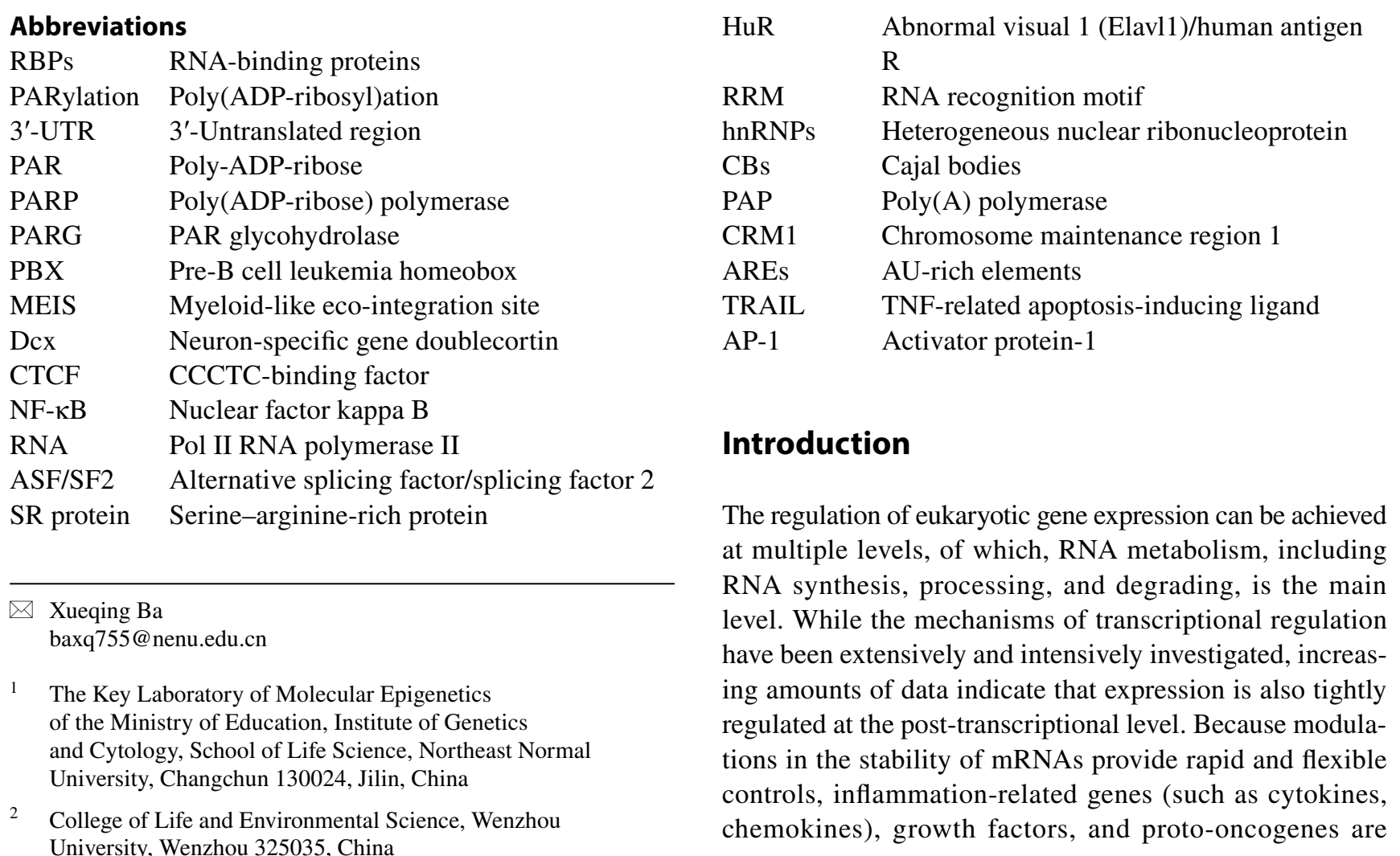


more dependent on post-transcriptional regulation [1,2]. Pre-mRNA must undergo alternative splicing, polyadenylation, cytoplasmic translocation, and translation to transfer genetic information into the protein form. RNA-binding proteins (RBPs) play a central role during RNA transactions by acting as trans factors, and the dysregulation of RBP expression or function can cause a variety of human diseases [3-5]; however, little is known about the regulation of RBP activities in RNA metabolism. Recently, some RBPs that are post-translationally modified by poly(ADP-ribosyl) ation (PARylation) to regulate RNA processing, including splicing, polyadenylation, and mRNA turnover, have been identified [4, 6]. A new perspective of poly(ADP-ribose) polymerase (PARP) biology involving mRNA metabolism at the post-transcriptional level is emerging. In this review, along with updating the current knowledge on the roles of PARP in transcriptional regulation, we summarized the evidence showing the roles of PARPs and PARylation in other aspects of RNA metabolisms.

\section{Poly ADP-ribosylation and the PARP superfamily}

Using $\mathrm{NAD}^{+}$as a substrate, PARPs catalyze the transfer of a negatively charged ADP-ribose polymer subunit to a target protein [7], and this post-translational modification is defined as PARylation (Fig. 1). Members of the PARP family are localized in a variety of cellular compartments, including the nuclei, cytoplasm and mitochondria [8]. Several PARP members (PARP1, 2, and 5) are currently considered to be poly-ADP-ribosyl transferases, while other PARP members (PARP 3, 4, 6-8, and 10-16) have been temporarily reclassified as mono-ADP-ribosyl transferases. Two members of this

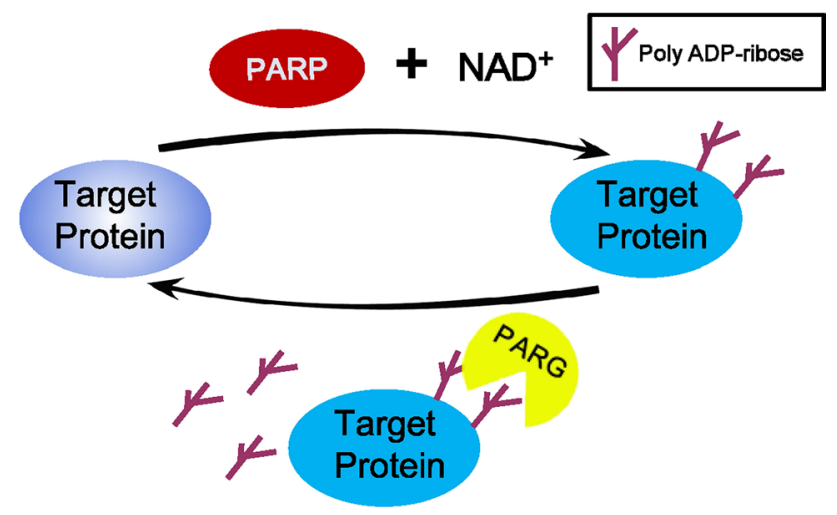

Fig. 1 Poly ADP-ribosylation turnover. Poly (ADP-ribose) polymerase (PARP) utilizes $\mathrm{NAD}^{+}$to create poly ADP-ribose, which then is attached to target proteins. In turn, the poly (ADP-ribose) glycohydrolase (PARG) removes poly ADP-ribose from target proteins, achieving the turnover of poly ADP-ribosylation family (PARP9 and 13) appear to lack any enzymatic activity [9] (Table 1), and five PARPs (PARPs 7, 10, and 12-14) contain well-characterized RNA-binding domains, which are defined as RBPs [10]. The PARylation target proteins are either mono ADP-ribosylated or modified with 2-500 ADP-ribose units that profoundly affect the localization or function of the target protein [7]. PARylation is a reversible process, and the covalently attached PAR can be hydrolyzed to free PAR by PAR glycohydrolase (PARG) (Fig. 1). In addition to covalently PARylating proteins at specific amino acid positions, reading PAR signals by PAR-binding proteins constitutes a major aspect of PAR biology [11]. Besides the four distinct classical protein modules, PAR-binding motif (PBM), PAR-binding zinc finger (PBZ), WWE domains and Macro domains, well-characterized PAR reader modules are also newly reported, such as breast cancer $1 \mathrm{C}$-terminal, RNA recognition motif (RRM), serine/arginine-rich (SR) and lysine- and arginine-rich (KR) domains [9, 11, 12]. Free PAR acts as a death messenger, causing cells to undergo AIF-mediated cell death (parthanatos) [13-15], representing another major biofunction of PARylation that is beyond the scope of this review. The balance between the activation levels of PARP and PARG determines cell fate, by influencing both the level of energetic substrates $\left(\mathrm{NAD}^{+}\right.$and ATP) and amount of PAR, which has been investigated in recent studies [16-20].

PARP1, the best studied and understood member of the PARP family, is a 116-kDa protein and can be divided into three functional domains. The N-terminal 46-kDa DNA-binding domain contains three zinc-binding domains (Zn1, Zn2, and $\mathrm{Zn} 3$ ) and a nuclear localization sequence. The first two zinc fingers appear to play different roles in the recognition of DNA breaks and enzyme activation, and they are both required to stimulate the activation of PARP1 in response to DNA single-strand breaks, but only the first zinc finger is required for the activation of PARP1 by double-strand DNA breaks [21]. A nuclear localization signal and a caspase- 3 cleavage site within the DNA-binding domain are located between the $\mathrm{Zn} 2$ and Zn3 fingers. The central auto-modification domain contains a large number of glutamate and aspartate residues, which is consistent with the primary site of PARP1 self-modification. The C-terminal catalytic domain (54 kDa), which is the most conserved domain across the PARP family, consists of a WGR motif and the "PARP signature". The WGR motif is defined by a conserved Trp, Gly, and Arg residue-rich domain, and the "PARP signature" sequence is required for the catalysis of PAR synthesis [22] (Fig. 2). As the most abundant and ubiquitous member of the PARP family, PARP1 accounts for nearly $90 \%$ of cellular PAR formation after genotoxic stress [23]. In the absence of DNA damage, the constitutive level of PAR is very low, and the PAR chain is relatively short and typically presents as an oligomer of a few ADP-ribose units [24]. However, in response to DNA damage, the synthesis of 
Table 1 List of poly (ADP-ribose) polymerase (PARP) family members

\begin{tabular}{lllll}
\hline $\begin{array}{l}\text { PARP family } \\
\text { member }\end{array}$ & Alternate name & $\begin{array}{l}\text { Predicted size } \\
(\mathrm{kDa})\end{array}$ & Subcelluar location & $\begin{array}{l}\text { Motifs and domains } \\
\text { Enzy- } \\
\text { matic } \\
\text { activity }\end{array}$ \\
\hline PARP1 & ARTD1 & 116 & Nucleus & Poly \\
PARP2 & ARTD2 & 63 & Nucleus & Zinc figers, WGR, BRCT \\
PARP3 & ARTD3 & 59 & Nucleus & WGR \\
PARP4 & ARTD4 & 190 & Cytosol & WGR \\
PARP5a & ARTD5, Tankyrase-1 & 146 & Nucleus, Cytosol & BRCT \\
PARP5b & ARTD6, Tankyrase-2 & 128 & Nucleus, Cytosol & Ankyrin repeat \\
PARP6 & ARTD17, tiPARPRMl & 35 & ND & Ankyrin repeat \\
PARP7 & ARTD14 & 72 & ND & Zinc figers, WWE \\
PARP8 & ARTD16 & 94 & ND & Poly \\
PARP9 & ARTD9, BAL1 & 94 & Nucleus, Cytosol & Macrodomain \\
PARP10 & ARTD10 & 113 & Nucleus, Cytosol & Mono \\
PARP11 & ARTD11 & 36 & ND & Wono \\
PARP12 & ARTD12, ZC3HDC1 & 77 & Cytosol (stress granules) & Zinc figers, WWE \\
PARP13 & ARTD13, ZC3HAV1, ZAP1 & 99 & Cytosol (stress granules) & Zinc figers, WWE \\
PARP14 & ARTD8, BAL2, COAST6 & 198 & Cytosol (stress granules) & Macrodomain, WWE \\
PARP15 & ARTD7, BAL3 & 49 & Cytosol (stress granules) & Macrodomain \\
PARP16 & ARTD15 & 69 & ND & Mono \\
\hline
\end{tabular}

ARTD ADP-ribosyl transferase, ZC3HAV1 zinc-finger CCCH-type antiviral protein 1, ZAP1 zinc-finger antiviral protein 1, COAST6 collaborator of signal transducer and activator of transcription 6,BAL B-aggressive lymphoma protein, $N D$ not determined, Poly poly-ADP-ribosyl transferases, Mono mono-ADP-ribosyltransferases

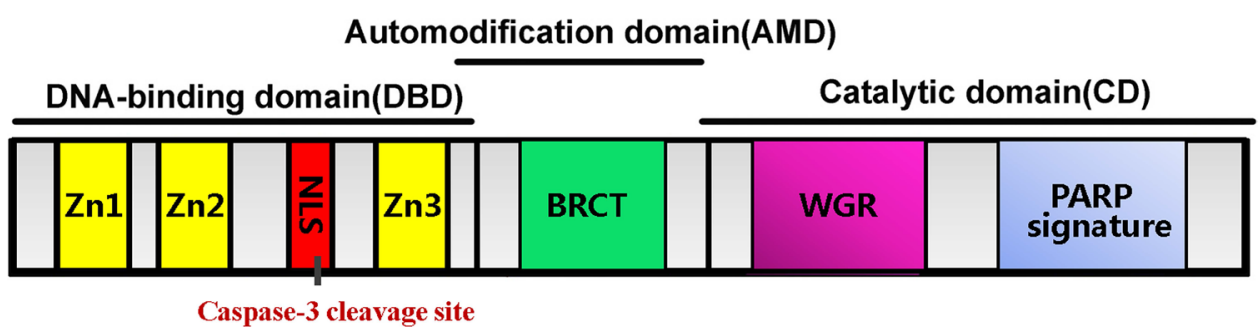

Fig. 2 Structural and functional organization of PARP1. PARP1 contains the following structural and functional domains: (1) a DNAbinding domain (amino acids 1-372), containing three zinc finger motifs (Zn1, Zn2, and Zn3) and a nuclear localization signal (NLS);

long and branched PAR chains increases from 10- to 500-fold [25]. A large amount of data indicate that PARP1 can respond to different types and levels of stress. The levels of PARP1 activity and PAR synthesis increase as the strength of the stress stimulus increases, resulting in different cellular outcomes. The interaction with DNA breaks organizes PARP1 domains into a collapsed conformation, which can explain the strong activation of PARP1 [7], and, consequently, PARP1 itself is usually the primary target of PARP1-mediated PARylation. The excessive activation of PARP1 may cause the depletion of $\mathrm{NAD}^{+}$and then ATP depletion, ultimately resulting in necrotic cell death [26]. Mild or moderate stress leads to DNA repair responses, which help maintain genomic stability or
(2) an automodification domain (amino acids 372-524), containing a BRCA1 C-terminus (BRCT) motif; and (3) a catalytic domain (amino acids 525-1014), containing the WGR (Trp-Gly-Arg) motif and the highly conserved PARP signature motif

transcriptional regulation, such as regulating genes in response to inflammatory stimuli [27-29]. Under conditions in which abundant DNA breaks are lacking, post-translational modifications, such as phosphorylation, acetylation and methylation, are alternative mechanisms for the regulation of PARP1 activity $[26,27]$. 


\section{PARP1 is involved in RNA synthesis/ transcription}

Over the past two decades, a growing amount of literature has revealed an important role for PARP1 in the regulation of gene expression. As an important nuclear protein, the altering of chromatin structure by modifying histones and acting as a component of enhancer/promoter-binding complexes are the two major mechanisms of PARP1 that affect transcription [30-32].

\section{PARP1 as a modulator of chromatin}

A large number of reviews have comprehensively summarized that PARP1 can automodify itself or PARylate histones, thereby, altering the chromatin structure [30-33]. The linker histone $\mathrm{H} 1$ has been identified as the major acceptor of PARylation [32, 34]. PARP1 and histone H1 compete for binding to target gene promoters, which contributes to the dynamic regulation of gene expression [35, 36]. In addition, PARP1 can maintain an open chromatin formation by preventing the demethylation of $\mathrm{H} 3 \mathrm{~K} 4 \mathrm{me} 3$. The PARylation of histone demethylase KDM5B inhibits its binding with chromatin, which promotes the loading of RNA polymerase II (RNA pol II) at the promoters of positively regulated target genes, allowing PARP1 to participate in transcriptional elongation [37]. As an intracellular sensor, PARP1 can be activated by various developmental signals and environmental cues, but how PARP1 is rapidly and specifically targeted to the physiologically correct gene loci is unknown. Recently, Hau and colleagues demonstrated that the transcriptional factors pre-B cell leukemia homeobox 1 (PBX1) and myeloid-like eco-integration site (MEIS) cooperate to induce chromatin opening by recruiting PARP1 when neural progenitor cells begin to differentiate into neurons [38]. Before differentiation, PBX1 is bound to the H1-compacted promoter/enhancer of the neuron-specific gene doublecortin $(D c x)$, essentially priming the gene for activation. Once differentiation is induced, MEIS associates with PBX1, and rapidly and specifically recruits PARP1 to the Dcx promoter/enhancer. This recruitment is associated with PARylation and the dismissal of histone $\mathrm{H} 1$, thereby facilitating $D c x$ gene expression [38]. The study suggested a novel mechanism and explained how PARP1 selectively targets promoters of downstream genes.

PARP1 is involved in the regulation of genomic DNA in the three-dimensional space. A chromatin insulatorbinding protein CCCTC-binding factor (CTCF) has been shown to be PARylated by PARP1. For example, in Drosophila, PARylation of CTCF-interacting protein CP190 promotes its interaction with insulator DNA-binding proteins, suggesting that PARylation regulates the ability of insulators to mediate contacts between distant sites in the genome $[39,40]$. Zhao et al. documented that PARP1 and CTCF not only mediate chromatin fiber interactions, but also trigger oscillations in the recruitment of circadian loci to the lamina, causing the silencing of these loci by the acquisition of repressive $\mathrm{H} 3 \mathrm{~K} 9 \mathrm{me} 2$ and transcriptional attenuation [41]. More recently, studies showed that PARP1 cooperates with CTCF to regulate Epstein-Barr virus latency. PARP1 and CTCF colocalize at specific sites throughout the viral genome, and CTCF is PARylated by PARP1 to maintain the open chromatin landscape and transcription in type III latency [42]. Importantly, the inhibition of PARP1 activity by the PARP inhibitor olaparib abrogates the recruitment of CTCF to the $\mathrm{C}$ promoter, which is the key control point in distinguishing type III latency, resulting in decreased type III latency-related transcription [42, 43]. Data collectively suggested that PARP1 activity may be integral to the function of insulators in organizing the three-dimensional architecture of the genome to regulate gene expression.

On the other hand, free PAR generated by PARP1 has been shown to serve as a dynamic source of ATP, which is required for the activity of ATP-dependent chromatinremodeling enzymes during cellular signaling [17]. Free PAR could be further broken down by pyrophosphatase NUDIX5 to produce ATP in the presence of pyrophosphate. The locally generated ATP participates in chromatin remodeling for the activation of transcriptional programs in response to hormone-dependent signaling [17].

\section{PARP1 as a transcriptional coregulator}

In addition to modulating transcription through alterations in chromatin structure, PARP1 also regulates the activities of enhancers and promoters either positively or negatively $[32,44]$. Nuclear factor kappa (NF-kB) exists as homo- or heterodimer that is made up of two subunits of RelA/p65, RelB, c-Rel, p50 and p52 [45]. NF- $\kappa B$ can be activated by PARP1 through various pathways. PARP1 may interact with histone acetyltransferases p300 and CREB-binding protein to activate NF- $\mathrm{KB}$. Inflammatory stimulation triggers p300 and the CREB-binding protein's acetylation of PARP1, enhancing PARP1's interactions with $\mathrm{p} 50$, which would ultimately lead to NF- $\mathrm{KB}$ activation $[46,47]$. Moreover, the enzymatic activity of PARP1 is important for NF- $\kappa \mathrm{B}$ activation, and the PARylation of the p50/p65 dimer or automodification of PARP1 appears to be critical for their binding to DNA and subsequent transcriptional activation. For example, in lipopolysaccharide (LPS)-treated smooth muscle cells, PARP1 could PARylate p65 and increase the binding of p65 with CRM1, thus inducing p65's nuclear 
retention and transcriptional function [48]. Additionally, in LPS-stimulated murine macrophage cells, the activated PARP1 PARylates the transcription factor NF- $\mathrm{KB}$ and promotes inflammatory genes' (such as $I l-1 \beta$ and $I l-18$ ) mRNA expression [27].

In response to DNA damage, activated PARP1 can influence the function and location of the p53 transcription factor. During DNA damage, super-activated PARP1 induces the PARylation of p53 [49]. The E255, D256, and E268 sites of p53 are critical for its PARylation, and the PARylation of p53 specifically blocks p53's interactions with the nuclear export factor CRM1, forcing p53's nuclear localization and favoring the activation of p53-dependent genes [49]. In addition to covalent PARylation, p53 also undergoes a noncovalent high-affinity interaction with PAR [50]. A new study showed that p53 noncovalently bound to auto-PARylated PARP1 through its C-terminal domain, which placed p53 in spatial proximity with the catalytic center of PARP1, resulting in a covalent PARylation of p53 by PARP1 [18]. Thus, noncovalent binding by PAR and the covalent PARylation of p53 are co-dependent, which affects p53-dependent DNAbinding properties and transcriptional functions.

In addition, $\mathrm{C} / \mathrm{EBP} \beta$, the key pro-adipogenic transcription factor, is PARylated by PARP1 on its K133, E135, and E139 amino acids, which are present in a conserved regulatory domain. The PARylation of C/EBP $\beta$ inhibits its DNA binding and transcriptional activities, which influences early events in the differentiation of adipocyte precursors [51].

\section{The function of PARP1 in RNA processing}

New discoveries have demonstrated that many RNA-binding proteins (RBPs) are modified by PARylation, thereby regulating gene expression at the post-transcriptional level [4, 6]. These studies have revealed new aspects of the PARPs' involvement in mRNA metabolism.

\section{Splicing}

Alternative splicing events play important roles in many cellular processes, including tissue-, cell type- and developmental stage-specific gene expression patterns in eukaryotes [52]. Alternative splicing is regulated by the binding of trans-acting factors to their target sites on pre-mRNA. These trans-acting factors promote or reduce the usage of a particular splice site [53]. In humans, almost $95 \%$ of multi-exonic genes are alternatively spliced $[54,55]$. The "co-transcriptional splicing hypothesis" suggests that factors affecting chromatin structure and stability also regulate alternative splicing [56]. Intriguingly, a recent study documented that PARP1 acts as an adapter molecule bridging chromatin and nascent mRNA, and as a recruiter of splicing factors (SFs).
PARP1 binds to nucleosomes at exon/intron boundaries corresponding to specific splice sites. Depletion of PARP1 or inhibition of its PARylation activity results in changes in the alternative splicing of a specific subset of genes [53]. PARP1 binds to specific nucleosomes (such as $\mathrm{H} 3 \mathrm{~K} 4 \mathrm{me} 3$ ) at exons and to the pre-mRNA. It then recruits the SF $3 \mathrm{~B}$ subunit 1 (SF3B1), a component of the U2 snRNPs. Knockdown of PARP1 impaired the association of SF3B1 to nucleosomes, whereas inhibition of PARylation had no significant effect [53]. U2 binds to the branch point recognized by the splicing machinery, allowing PARP1 to influence exon recognition and the splicing process [53] (Fig. 3a). PARP1 has been proved to be a novel mRNA-binding protein that preferentially binds RNAs containing GC-rich regions [57]. In the absence of the $\mathrm{Zn} 1$ and $\mathrm{Zn} 2$ domains, PARP1 switches from a DNA binder to an RNA binder, indicating that the $\mathrm{Zn} 1$ and $\mathrm{Zn} 2$ domains of PARP1 bind to chromatin and that PARP1 still has the ability to bind to mRNA through another domain [57]. A most recent follow-up study reported that PARP1 influences alternative splicing decisions through the regulation of RNAPII elongation. Genome-wide analyses confirmed that PARP1 influences the changes in RNAPII elongation by either reducing or increasing the rate of RNAPII elongation depending on the chromatin context, delineating PARP1's role in RNA biogenesis and processing [58].

Additionally, PARP1 also plays a role in splicing by altering the RNA-binding dynamics of heterogeneous nuclear ribonucleoproteins (hnRNPs). In 2003, a proteomic approach demonstrated that hnRNPs can establish a strong noncovalent link with PAR. Specifically, the conserved domain located between RRM1 and RRM2 of hnRNPA1 is the PAR-binding motif [59]. HnRNPs, as a group of RBPs, in addition to the function in splicing, also mediate multiple steps of RNA processing, such as mRNA export, localization, translation, and stability [60]. To date, 11 human hnRNP proteins have been identified as PAR readers. In Drosophila, hnRNPs can either promote or inhibit splicing by binding with exonic and intronic splicing enhancers or silencers, and PAR binding to hnRNPs causes the dissociation of hnRNPs from RNA, which influences intron splicing [4, 61] (Fig. 3b). Alternative splicing factor/splicing factor 2 (ASF/SF2), a prototypical serine-arginine-rich (SR) protein, is involved in splicing regulation. PAR may bind to the splicing factor ASF/SF2 through either the RRM1 or SR-rich C-terminal domain, and it inhibits phosphorylation by DNA topoisomerase I in HeLa nuclear extracts [62]. DNA topoisomerase I has dual roles in transcription, controlling DNA supercoiling or acting as a specific kinase for the SR protein family of splicing factors [63]. Because ASF/SF2 phosphorylation can promote splicing [64], PAR binding to SR proteins may also regulate alternative splicing by modulating the phosphorylation of SR proteins. 
a

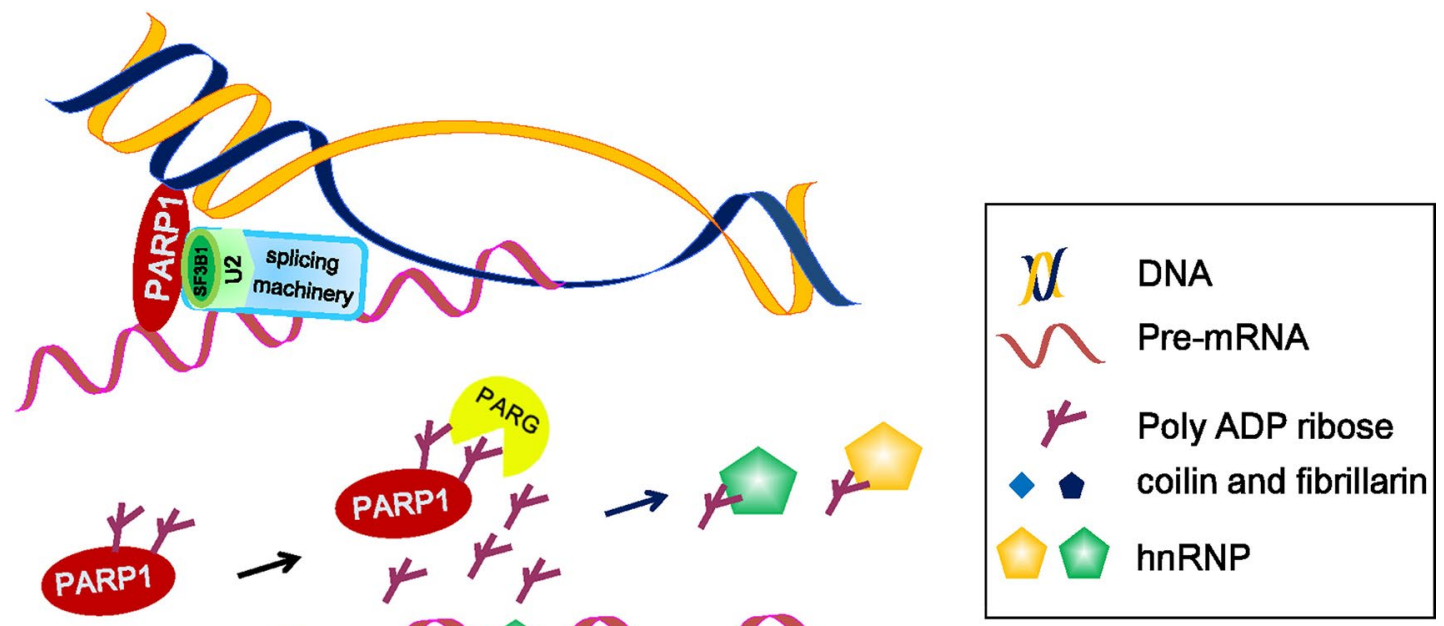

b

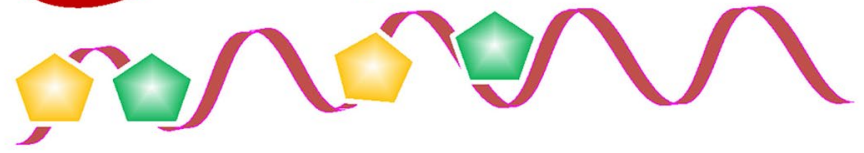

C

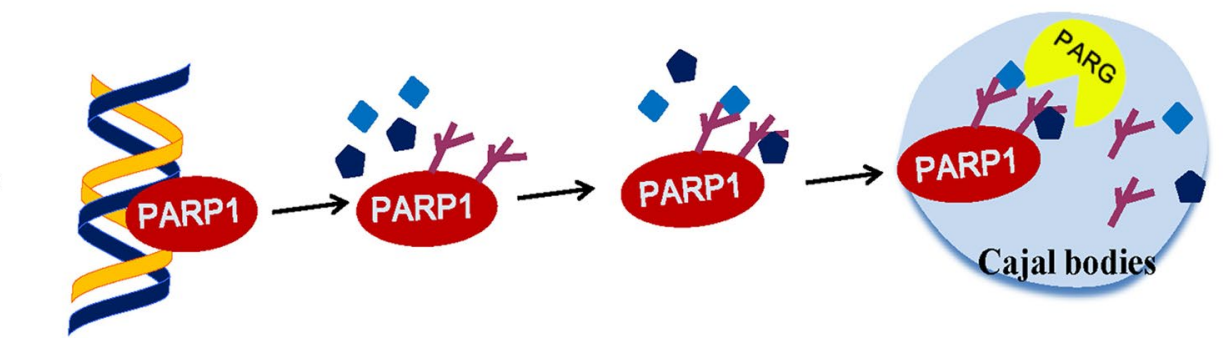

Fig. 3 The function of PARP1 in RNA splicing. a Model of PARP1 in mediating alternative splicing. PARP1 binds to specific nucleosomes at exons and to the pre-mRNA. It then recruits the SF $3 \mathrm{~B}$ subunit 1 (SF3B1), a component of the U2 snRNPs. U2 binds to the branch point recognized by the splicing machinery, allowing PARP1 to influence the splicing process [53]. b Model of PARP1 in the regulation of hnRNP functions. PAR binding to hnRNPs causes the dis-

Cajal bodies (CBs) are nuclear organelles in proliferative cells, which contain small nuclear ribonucleoproteins, small nucleolar RNPs, RNA pol II transcription factors and nuclear proteins [65]. CBs are involved in many RNA metabolic processes, such as transcription and pre-mRNA splicing [66]. Under stress conditions, autoPARylated PARP1 gains the ability to bind to a number of nuclear proteins. At this time, the automatically modified PARP1 acts as a shuttle protein to deliver the protein components to the $\mathrm{CB}$ to regulate its assembly and disassembly and to further regulate transcription and splicing [67]. For example, under physiological conditions, unmodified PARP1 binds to chromatin and accumulates in the nucleolus. Upon activation, autoPARylated PARP1 interacts with coilin and fibrillarin, two key protein components of CBs, in a PAR-dependent manner and increases the migration of the two proteins from chromatin into CBs. In CBs, the complex is disassembled by PARG cleavage, and coilin and fibrillarin proteins are sociation of hnRNPs from RNA, which enhances or inhibits intron splicing $[4,59,61]$. $\mathbf{c}$ Model of protein delivery to Cajal bodies (CBs) by PARP1. Upon activation, autoPARylated PARP1 interacts with coilin and fibrillarin, and then the complex, consisting of auto-modified PARP1 and proteins, migrates into the CBs. In CBs, the complex is disassembled as a result of poly ADP ribose cleavage, and the released proteins are recycled [67]

released [67] (Fig. 3c). These findings indicate that PARP1 and PAR affect transcription and splicing by regulation $\mathrm{CB}$ biogenesis and dynamics.

\section{Polyadenylation}

Remarkably, almost all human pre-mRNAs possess multiple cleavage sites and polyadenylation signals in their 3'-untranslated region (3'-UTR) [68]. The generation of mature mRNA $3^{\prime}$ ends primarily consists of two reactions, endonucleolytic cleavage catalyzed by polyadenylation specificity factor and the synthesis of a poly(A) tail onto the 5 '-cleaved product by poly(A) polymerase (PAP). The human pre-mRNA 3'-processing complex contains approximately 85 proteins, and PARP1 has been identified as a related factor, implying a role for PARP1 in processing complex assembly and function $[69,70]$ (Fig. 4a). PARP1 binds and PARylates PAP in vitro, which in turn prevents 


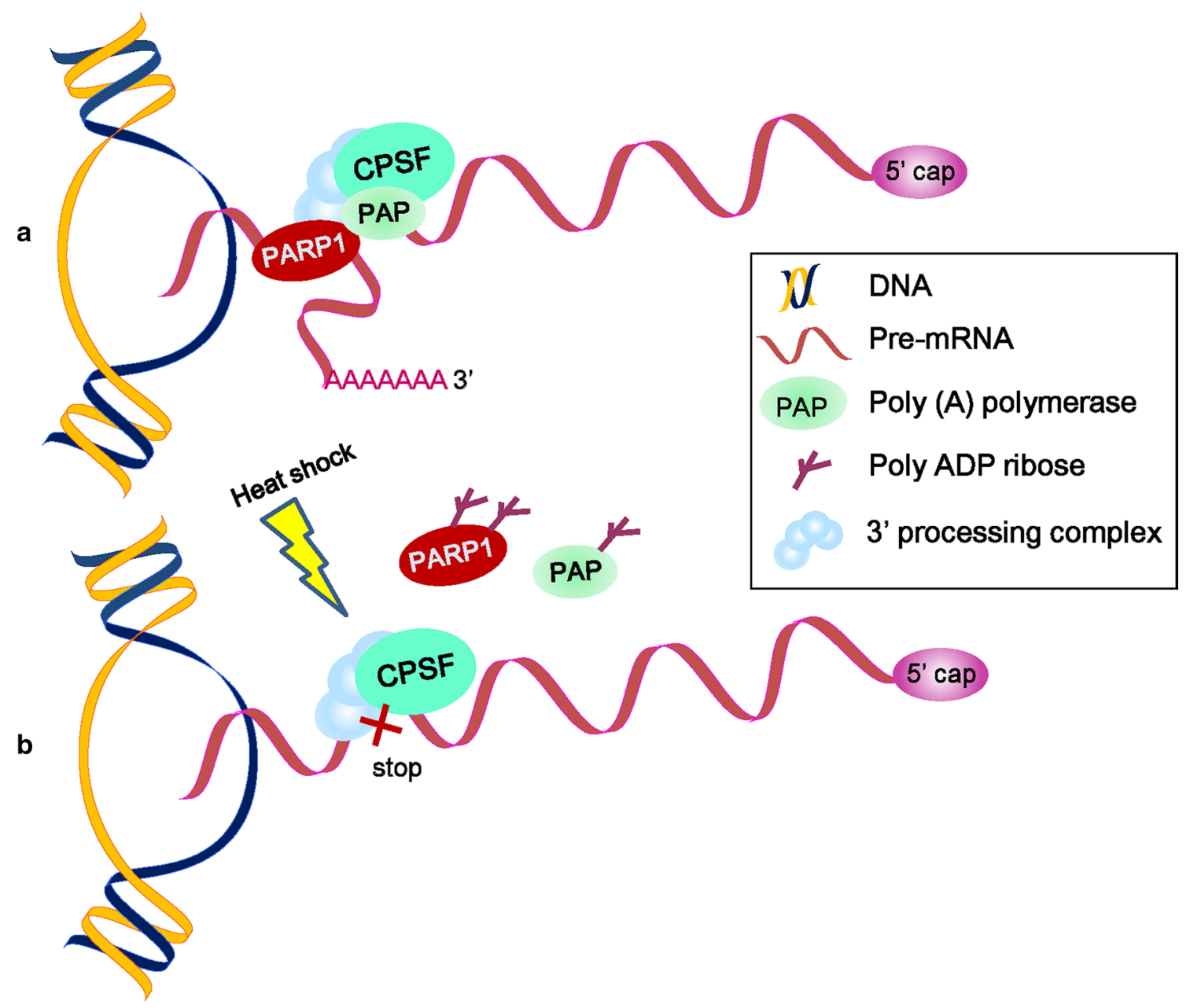

Fig. 4 The function of PARP in pre-mRNA polyadenylation under heat-shock conditions [70]. a Under normal conditions, polyadenylation specificity factor (CPSF) and poly(A) polymerase (PAP) together with the 3'-processing complex bind pre-mRNAs. Pre-mRNAs' $3^{\prime}$ cleavage and polyadenylation occur normally. b The activated

PAP from associating with most mRNA transcripts, inhibiting polyadenylation and mature mRNA synthesis under heat-shock conditions [70] (Fig. 4b). Surprisingly, the $\gamma$-irradiation $(\gamma$-IR) and oxidative stress are unable to redirect PARP1 activity toward PAP and inhibit polyadenylation [70]. Because PARP1's activation during heat shock may be directed by some unknown molecular mechanism, PARylated PAP influences the mRNA maturation process only under heat-shock conditions. Polyadenylation contributes to many aspects of mRNA metabolism, including mRNA export to the cytoplasm, mRNA stability, and the translation efficiency [71]. During heat shock, the polyadenylate-ome subjected to regulation by PARylated PAP may be necessary for us to further understand the crucial role of PARP1 in mRNA processing.
PARP1 PARylates PAP under heat-shock conditions, which causes the dissociation of PAP and PARP1 from RNA, leading to the inhibition of pre-mRNA polyadenylation and the repression of mRNA maturation

\section{Nuclear export}

Eukaryotic gene expression requires the export of proteincoding mRNAs and non-coding RNA molecules from the nucleus to the cytoplasm. The major classes of cellular RNAs are exported as RNA-protein complexes, which involves RBPs as well as receptor proteins that interact with the nuclear pore complexes [72]. Although most mRNAs use transcription/export, transcription/export -2 , and nuclear RNA export factor 1 receptors to transit through nuclear pore complexes, a subset of mRNAs use chromosome maintenance region 1 (CRM1) as the receptor. As a key nuclear export receptor, CRM1 does not directly bind RNA or protein. Instead, CRM1 associates with adaptor proteins by recognizing a leucine-rich nuclear export signal 
[73]. Those mRNA containing AU-rich elements (AREs) in their 3'-UTRs belong to the early response genes [2], and the ARE-binding protein HuR, as an adapter protein, links RNA to CRM1 using the ligands pp32 and APRIL [74]. The HuR-CRM1 pathway mediates the export of some ARE-containing mRNAs, such as c-fos and CD83 [75, 76]. A recent study identified CRM1 together with HuR as nuclear exports that mediate the exportation of long noncoding RNA (lncRNA) RMRP [77]. RMRP is encoded by a nuclear DNA but has key functions in mitochondria, which are important for mitochondrial DNA replication and RNA processing [78, 79]. Furthermore, we found that in cells exposed to LPS, PARP1 binds to HuR and increases HuR's PARylation at the D226 site. PARP1 inhibition or D226 mutation diminishes the enhanced nucleocytoplasmic translocation of HuR [6]. While the hypomethylation at R217 and dephosphorylation at S221 have been attributed to the impaired interaction of HuR with CRM1 and its subsequent mislocalization [80], PARP1's involvement in CRM1mediated RNA nuclear export is plausible, although the study did not address the requirement of HuR's PARylation for its interaction with CRM1, either directly or indirectly
(Fig. 5). Interestingly, it has been reported that p65 PARylation decreased its interaction with CRM1 in vitro. The pharmacologic inhibition of PARP1 increased the NF- $\kappa \mathrm{B}-\mathrm{CRM} 1$ interaction in LPS-treated smooth muscle cells, suggesting that p65 PARylation may be a critical determinant for the interaction of NF- $\mathrm{kB}$ with CRM1, NF- $\mathrm{KB}$ nuclear retention and gene expression upon TLR4 stimulation [48]. These studies implied that PARP1 has different effects on the CRM1-mediated nucleocytoplasmic shuttling of the PARylated cargo proteins.

\section{A novel function of PARP1 in regulation of mRNA stability}

The amount of protein generated from any given mRNA depends not only on the rate of mRNA translation, but also on the rates of mRNA synthesis and decay. Thus, mRNA stability provides an additional crucial layer of regulation at the post-transcriptional stage of gene expression. Genetic deletions of PARP1 or pharmacological blockades of PARPs activity in mice result in defective inflammatory immune

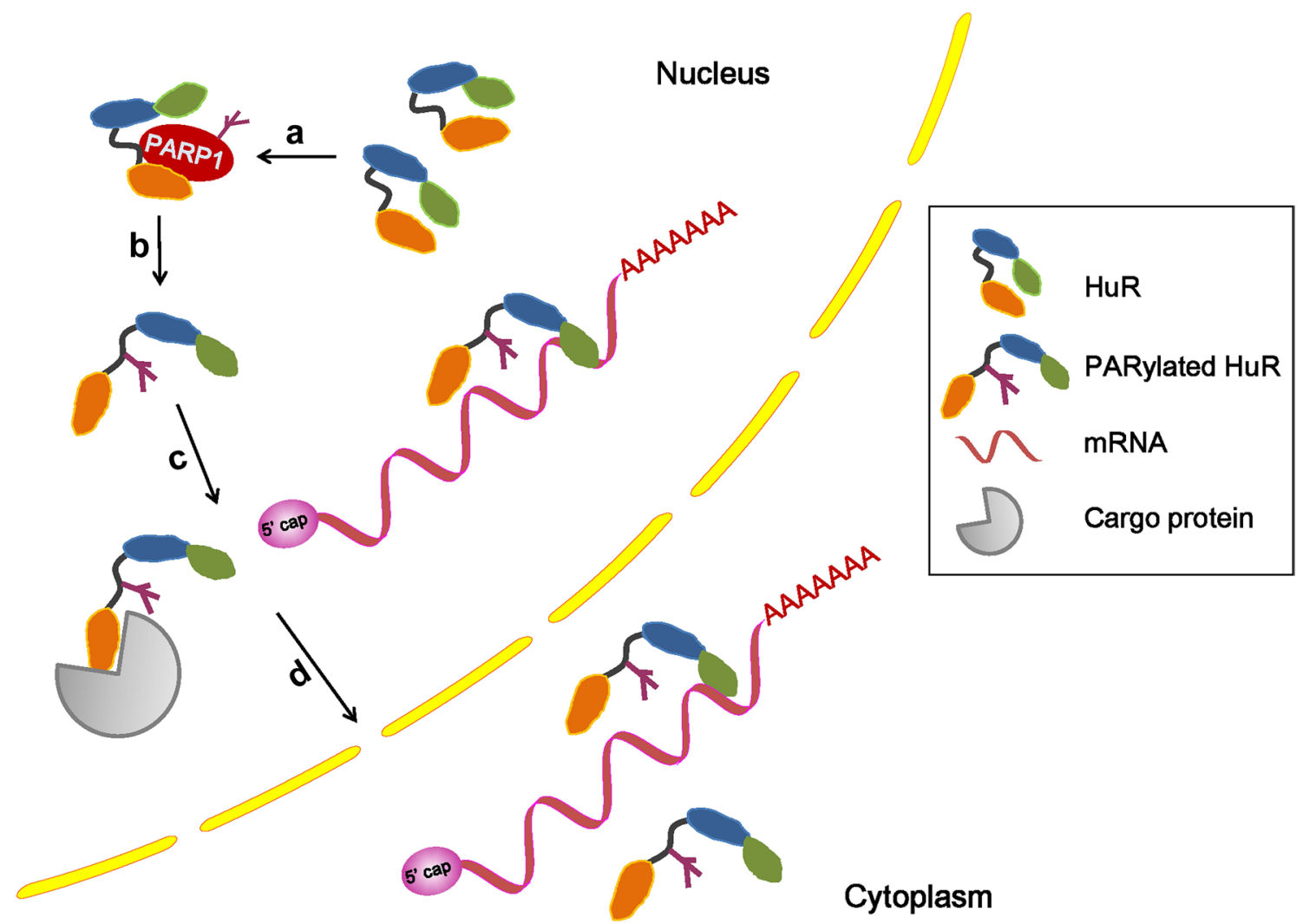

Fig. 5 Model in which PARP1 PARylates HuR and influences its location and function [6]. a The activated PARP1 binds and PARylates the HuR protein; $\mathbf{b}$ the PARylation of HuR alters protein properties; $\mathbf{c}$ the exposure of the HuR nuclear export sequence offers more opportunities for it to be recognized by carrier proteins; and $\mathbf{d}$ the accumulation of $\mathrm{HuR}$ in cytoplasm leads to the functional activation of HuR, allowing it to bind target mRNAs 
responses [29]. However, the role of PARP1 in the regulation of inflammatory gene expression at the post-transcriptional level, and especially its effects on mRNA stability, is still less studied. Interferon- $\gamma$-inducible protein-10 (IP-10), a member of the CXC family of chemotactic factors, is a potent chemoattractant for $\mathrm{T}$ - and natural killer cells [81, 82]. In 2010, Galbis-Martínez et al. showed that PARP1's depletion did not influence the activity of the IP-10 promoter, but the expression of $I P-10 \mathrm{mRNA}$ induced by interferon (IFN)- $\gamma$ is diminished in Parp $^{-1-}$ mouse embryonic fibroblasts, suggesting that PARP1 regulates the IP-10 mRNA level by increasing mRNA stability, although the study did not dissect the precise molecular mechanism of how PARP1 influences the mRNA level of IP-10 [83].

The regulation of mRNA stability involves both cis elements that are harbored in mRNA and the cognate trans factors. Among them, ARE and ARE-binding proteins have attracted the most attention. Up to $8 \%-10 \%$ of the genes in the human genome contain at least one putative ARE in their 3'-UTR [84]. AREs are found in the tightly regulated mRNAs that encode proto-oncogene proteins (e.g., c-Fos and c-Myc) and inflammatory mediators (e.g., CXCL2 and IL-1 $\beta$ ). Most ARE-binding proteins function as negative regulators by decreasing mRNA stability or translation, e.g., tristetraprolin, AU-rich element RNA-binding protein 1 and TIA-1-related protein [2], while HuR is one of the few that stabilizes ARE-containing mRNAs.

$\mathrm{HuR}$ is a member of the embryonic lethal abnormal vision family. Unlike other members $(\mathrm{HuB}, \mathrm{HuC}$, and $\mathrm{HuD})$ of the family, which have tissue-specific expressions, HuR is ubiquitously expressed in almost all types of cells [2, 85]. HuR is localized predominately in the nucleus and shuttled into the cytoplasm using a shuttling sequence HNS under various stress conditions [86]. HuR may compete with degradation proteins and prevent them from transporting the mRNAs to the decay structure, the exosome [87]. The functional regulation of HuR is achieved through protein modifications, such as phosphorylation, methylation and ubiquitination [19, 88-92]. Recently, it was reported that inflammatory stimuli can induce PARP1 interactions with HuR and PARylates it at the D226 site, which is located in the HNS domain. It was documented that the PARylation could not only enhance the nuclear-cytoplasmic shuttling of HuR, but also increase the association of HuR with target mRNAs. Unlike other studies that usually investigated the binding of HuR with mRNA in cytoplasm, the increased formation of protein-mRNA complexes upon HuR PARylation was detectable both in the nucleus and cytoplasm, which may mean PARylation not only enhances shuttling of HuR but also accelerates nuclear cytoplasmic delivery of HuR's target. PCR array analyses of inflammatory cytokines and chemokines showed that the PARP1-HuR signal influences the stability of a set of ARE-containing mRNAs, such as $\mathrm{Cxcll}, \mathrm{Cxcll3}$, and
Il-1 $\beta$ [6]. The mechanism of how PARP1-HuR interaction regulates mRNA stability is illustrated as follows: (a) the activated PARP1 binds with and PARylates HuR at the HNS domain; (b) the PARylation alters the conformational properties of the HuR protein, which likely exposes the nuclear export sequence for translocation and the RRM for binding with mRNAs; (c) the exposure of nuclear export sequence increases the opportunity of HuR (itself or complexed with mRNAs) to be recognized by export proteins, such as CRM1 or transportin-2; and (d) the accumulation of HuR in the cytoplasm leads to the functional execution of HuR (Fig. 5). Recently, Chand et al. showed that, in pancreatic ductal adenocarcinomas cells, under DNA-damaging conditions, PARP1 binds with HuR and increases the shuttling of HuR to the cytoplasm, where HuR stabilizes PARG mRNA and promotes protein expression, enhancing DNA repair [93]. Thus, there appears to be a new aspect of PARP1 biology in gene expression regulation at the post-transcriptional level by stabilizing target mRNAs.

\section{Other PARPs in RNA regulation}

Although much of the focus has been on PARP1, studies over the past decade have begun to reveal the physiological and pathological roles of the other PARP family members, with many new and exciting functions being identified [31, 94-96]. Below, we highlight some of the key results regarding cytoplasmic PARPs in RNA regulation.

mRNA and microRNA (miRNA) form dense aggregated structures called stress granules to stop translation when cells are under stress conditions [97]. Stress granules are cytoplasmic, non-membranous structures that form within minutes of exposure to stress and dissolve within a few hours of stress recovery. Six members of the PARP family, including PARP5a, 12, 13.1, 13.2, 14, and 15, together with two forms of PARG (PARG99 and PARG102) in the cytosol participate in the miRNA-related activities in the stress granules. MiRNAs bind to target mRNAs, which leads to the translational repression and decay of the target mRNAs, and this process requires the Ago protein (Fig. 6a). The PARylation of Ago decreases its binding with target mRNAs and reduces its silencing activity (Fig. 6b) [98].

PARP12, a Golgi-localized single ADP-ribosyltransferase of the PARP family, functions in cell survival and anti-viral responses [99]. The activation of PARP1 and PAR release from the nucleus lead to PARP12 translocation from the Golgi complex to stress granules (Fig. 6c), and the zinc finger and WWE domains of PARP12 are necessary for its PAR binding and translocation [100]. PAR binding with PARP12 contributes to shutting down translation and to the cross talk between members of the PARP family involved in gene expression at the post-transcriptional level. 


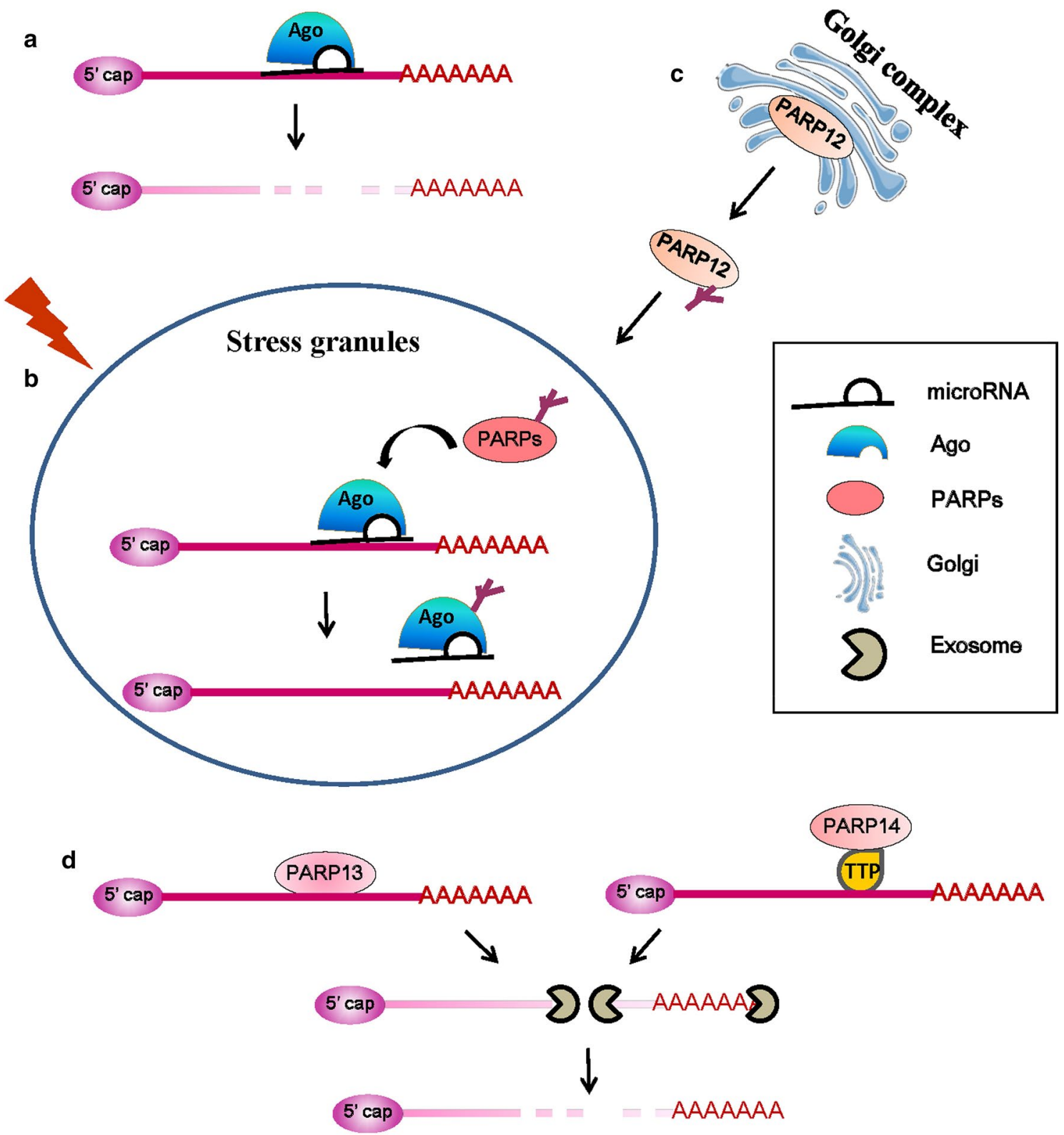

Fig. 6 PARP family members involved in RNA regulation. a MicroRNAs and Ago bind to target mRNAs, which leads to the decay of the target mRNAs. b The activated PARP family member PARylates the Ago protein in stress granules (SG), which decreases it's binding with target mRNAs and reduces its silencing activity under stress

PARP13, also known as ZC3HAV1 and zinc-finger antiviral protein (ZAP), is an RBP. PARP13 binds RNAs of viral origin during infection and then recruits RNA-decay factors, such as exosome complexes to degrade RNA [101]. PARP13 also regulates miRNA through Ago inhibition by targeting Ago proteins for PARylation [98]. The global repression of miRNA silencing results in the up-regulation of pro-inflammatory cytokines and common miRNA targets, and helps mount the antiviral response. In addition to its antiviral functions, PARP13 also binds to cellular conditions [98]. $\mathbf{c}$ The activation of PARP1 and PAR release increase PARP12's translocation from the Golgi complex to SG [100]. d PARP13 and PARP14 promote the degradation of specific transcripts by targeting them to the cellular RNA decay machinery $[102,105]$

RNA. A major target of PARP13 regulation is TNF-related apoptosis-inducing ligand receptor 4 (TRAILR4) mRNA, which encodes a member of the TRAIL receptor family. PARP13 destabilizes TRAILR4 mRNA post-transcriptionally, but has no effect on the mRNA levels of other TRAIL receptors [102]. PARP13 binds to the 3'-UTR of TRAILR4 through its $\mathrm{CCCH}$ domain and promotes TRAILR4 mRNA degradation via the RNA exosome complex [101] (Fig. 6d left). Thus, by targeting TRAILR4 mRNA, PARP13 acts 
as a pro-apoptotic factor and may increase the cellular response to TRAIL in transformed cells [102].

PARP14, a member of the PARP family, is a pro-survival protein that has been reported as being involved in protecting lymphocytes from apoptosis [103, 104]. Additionally, a recent study showed that PARP14 is involved in mRNA stability regulation [105]. PARP14 interacts with tristetraprolin, one of the dominant mRNA-destabilizing factors [68], and forms a complex that binds to the 3'-UTR of tissue factor mRNA, thereby promoting its degradation [105] (Fig. 6d, right).

\section{Involvement of PARPs in inflammation}

Inflammation plays critical roles in host defense responses and damage repair, and it is also a common underlying cause of many diseases and is recognized as a hallmark of many cancers [106, 107]. Over the past years, a large number of studies have addressed the involvement of PARPs in the progression of different pathological processes, such as lung inflammatory disorders, cardiovascular disorders, breast cancer, and diabetes [27, 47, 108-116]. Here, we focus on the implications of PARPs in the process of inflammation.

Pro-inflammatory factors, such as cytokines and chemokines, are key mediators of inflammation and host defenses, and their regulation is largely dependent on related transcription factors. As mentioned above, many transcription factors that are involved in the inflammatory process, such as activator protein-1 (AP-1), p53 and NF- $\mathrm{KB}$, have been reported to be regulated by PARP1 [18, 48, 108-114, 117, 118]. The PARylation of the transcription factors will affect their intracellular localization, stability, or ability to bind with the target gene promoter, which in turn affects the expression of pro-inflammatory factors [117-121]. For example, PARP1 increases the production of pro-inflammatory cytokines, such as TNF $\alpha$, IL-5, and Cxcl2, by activating the NF- $\mathrm{KB}$ pathway, which plays important roles in the pathogenesis of asthma, acute lung injury, and chronic obstructive pulmonary disease [27, 108, 122]. Kiefmann et al. showed that PARP1 contributes to acute lung injury via the up-regulation of iNOS through the activation of AP-1, but not NF- $\mathrm{KB}$ during endotoxemia [123]. In addition, the mRNA stability of a series of pro-inflammatory chemokines ( $\mathrm{Cxcll}, \mathrm{Cxcl} 2, \mathrm{Cxcll3}$, and $\mathrm{Il}-1 \beta)$ is influenced by PARP1-HuR signals (see above) [6], which also suggests a potential strategy to treat diseases closely associated with mRNA stability. Furthermore, HuR can bind PARG mRNA under PARP inhibitor stress, and the inhibition of HuR combined with PARG mRNA helps to improve the effectiveness of PARP inhibitory therapy in pancreatic cancer cells [93]. The RNA-binding proteins hnRNPs, which noncovalently bind with PAR, are involved in many neurodegenerative diseases, including fragile X syndrome, Alzheimer's disease, and amyotrophic lateral sclerosis [4]. Although the study did not define PARP1's function, PAR binding to hnRNPs caused the dissociation of hnRNPs from RNA, suggesting a reduction in hnRNP's noncovalent bonds with PAR by a PARP inhibitor may improve treatments for neurodegenerative diseases [4, 61, 124] (Table 2).

Studies on other members of the PARP family in the inflammatory process have also emerged. The closest homolog of PARP1 is PARP2, which is able to PARylate itself or other target proteins [125]. PARP2 has also been reported to regulate neuroinflammatory responses. $P A R P 2^{-/-}$mice showed an attenuated neuronal inflammation and reduced spinal inflammatory cell infiltration and demyelination [126]. Furthermore, the PARP members localized in the cytoplasm participate in the regulation of inflammatory gene expression. In response to the stimulation of cytokine IL- $1 \beta$ or TNF $\alpha$, PARP10 represses the activation of NF- $\kappa \mathrm{B}$ and downstream the expression of target genes and proteins (i.e., IL-8) in HeLa and U2OS cells [127], whereas the overexpression of PARP12 activates NF- $\mathrm{KB}$ signaling and promotes IL- 8 secretion in response to an extracellular ligand [99]. The RNA-binding protein PARP13 is another PARP family member. In addition to its role in targeting viral RNA degradation, its activity has also been reported to prevent cancer [101]. By inhibiting the expression of the pro-survival receptor TRAILR4, PARP13 helps to sensitize cells to TRAIL-mediated apoptosis, thereby limiting cancer cell survival [102]. In fact, multiple cancerous tumors exhibit a low expression of PARP13 compared with normal tissues, suggesting that PARP13 is an important pro-inflammatory and pro-apoptotic agent [101]. Additionally, PARP14 is highly expressed in diverse solid tumors, PARP14-deficient animals show reduced lung pathology compared with control animals [128], and PARP14 promotes the Warburg effect by inhibiting JNK1-dependent PKM2 phosphorylation [129] (Table 2). Thus, PARP inhibition may extend to treatments of inflammation-related diseases, besides its conventional application in cancer therapy.

\section{Conclusions}

PARPs modulate the molecular biology and biochemistry of stress responses at multiple levels. In addition to the important roles of PARP1 in DNA damage detection and repair, its roles in RNA biology, gene regulation, and cytoplasmic functions have now emerged (Fig. 7). Although a large body of evidence has accumulated over the past decade, many questions still remain. Our understanding of the roles of PARPs in the regulation of gene expression, especially at the post-transcriptional level, is still in the early stage. PARPs, together with PARG, participate in many RNA 
Table 2 Studies on the roles of PARPs involved in inflammation

\begin{tabular}{|c|c|c|c|c|c|c|}
\hline PARPs & Factors & Target genes & RNA metabolism & Functions & Pathological process/model & References \\
\hline PARP1 & NF-кB & $\begin{array}{l}\text { TNFa, } \\
\text { INFy, IL6, } \\
\text { MMP... }\end{array}$ & Transcription & $\begin{array}{l}\text { PARP1 fuels NF-KB-driven inflam- } \\
\text { mation gene expression }\end{array}$ & Asthma, breast cancer, diabetes... & {$[48,108-114]$} \\
\hline PARP1 & AP-1 & iNOS & Transcription & $\begin{array}{l}\text { PARP1 contributes to acute lung } \\
\text { injury via up-regulation of iNOS } \\
\text { through activation of AP-1 }\end{array}$ & Acute lung injury & [123] \\
\hline PARP1 & NFAT & IL-2 & Transcription & $\begin{array}{l}\text { PARPl positively regulate NFAT- } \\
\text { dependent cytokine gene tran- } \\
\text { scription }\end{array}$ & Acute inflammation & [117] \\
\hline PARP1 & STAT-6 & IL-5 & Transcription & $\begin{array}{l}\text { PARPl affects IL-5 expression } \\
\text { through regulation of STAT- } 6 \\
\text { nrotein inteeritv }\end{array}$ & Asthma & [122] \\
\hline PARP1 & Snail & E-cadherin & Transcription & $\begin{array}{l}\text { PARPl inhibits E-cadherin promoter } \\
\text { activity by upregulating Snail } \\
\text { protein stability }\end{array}$ & Malignant melanoma & {$[120]$} \\
\hline PARP1 & HMGB1 & & Transcription & $\begin{array}{l}\text { PARPl increases the pro-inflamma- } \\
\text { tory mediator HMGB1 accumula- } \\
\text { tion in the cytosol }\end{array}$ & Necrosis & [119] \\
\hline PARP1 & KLF8 & CyclinDl & Transcription & $\begin{array}{l}\text { PARPl increases cancer related tran- } \\
\text { scriptional factor KLF8 nuclear } \\
\text { location and transcriptional } \\
\text { activity }\end{array}$ & Breast cancer & {$[121]$} \\
\hline PARP1 & $\mathrm{HuR}$ & PARG & mRNA stability & $\begin{array}{l}\text { Inhibition of HuR combines with } \\
\text { PARG mRNA helps to improve } \\
\text { PARP inhibition therapy in pan- } \\
\text { creatic cancer cells }\end{array}$ & Pancreatic ductal adenocarcinoma & [93] \\
\hline PARP1 & HuR & $\mathrm{Cxcl} 2$ & mRNA stability & $\begin{array}{l}\text { PARPl promotes pro-inflammation } \\
\text { gene expression by modulating the } \\
\text { RNA-binding protein HuR }\end{array}$ & Acute inflammation & [6] \\
\hline PARP1 & HnRNP & FMR1 & mRNA splicing & $\begin{array}{l}\text { PAR binding to hnRNPs causes } \\
\text { the dissociation of hnRNPs from } \\
\text { RNA }\end{array}$ & Neurodegenerative diseases & {$[4,60,61,124]$} \\
\hline PARP1 & p38 & IP-10 & mRNA stability & $\begin{array}{l}\text { PARPl regulates inflammatory } \\
\text { mRNA stability via modulating } \\
\text { p38 MAPK signalling A pathway }\end{array}$ & Acute inflammation & [83] \\
\hline PARP2 & & & & $\begin{array}{l}\text { The deletion of PARP2 reduces } \\
\text { spinal inflammation }\end{array}$ & Neuroinflammation & [126] \\
\hline PARP10 & NF-кB & IL-8 & Transcription & $\begin{array}{l}\text { PARP10 represses NF-KB-depend- } \\
\text { ent inflammation related gene and } \\
\text { protein expression }\end{array}$ & Chromic inflammation & [127] \\
\hline PARP12 & NF-кB & IL-8 & Transcription & $\begin{array}{l}\text { PARPI } 2 \text { activate the NF-KB signal } \\
\text { and promotes IL- } 8 \text { secretion in } \\
\text { response to an extracellular ligand }\end{array}$ & Microbial infections & [99] \\
\hline PARP13 & & TRAILR4 & mRNA stability & $\begin{array}{l}\text { PARPI3 binds to 3'UTR of } \\
\text { TRAILR } 4 \text { mRNA, and leads to its } \\
\text { degradation via the RNA exosome } \\
\text { complex }\end{array}$ & Apoptosis & [102] \\
\hline PARP14 & STAT6 & Gata3 & Transcription & $\begin{array}{l}\text { PARP14 modulates the binding of } \\
\text { STAT6 to the Gata3 promoter }\end{array}$ & Allergic airway disease & [128] \\
\hline PARP14 & PKM2 & & & $\begin{array}{l}\text { PARP } 14 \text { promotes the War- } \\
\text { burg effect by inhibiting JNK1 } \\
\text {-dependent PKM2 phosphoryla- } \\
\text { tion }\end{array}$ & Hepatocellular carcinoma & [129] \\
\hline
\end{tabular}

STAT-6 signal transducer and activator of transcription-6, EMT epithelial-mesenchymal transition, HMGB1 high mobility group box-1 protein, $K L F 8$ kruppel-like factor 8, PKM2 pyruvate kinase M2 isoform 


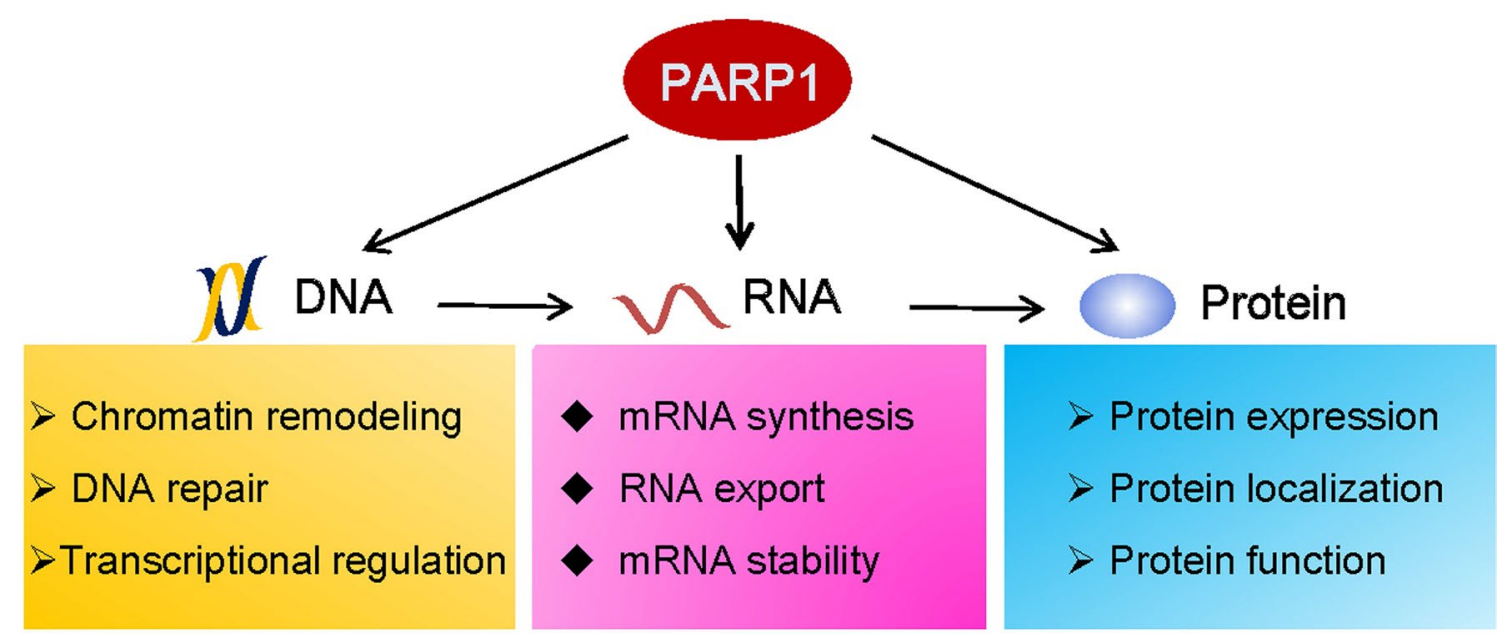

Fig. 7 PARP1 modulates cellular stress responses through a series of regulatory processes that occur at the DNA, RNA, and protein levels

metabolism-related processes, such as splicing, polyadenylation, mRNA maturation and translation by manipulating the functions and locations of RBPs. Recently, PARP1 was identified as a novel RBP. Although the range of mRNA types bound by PARP1 has not been explored in detail, it has been implied that PARP1 plays multiple and complex roles in RNA metabolism. In conclusion, the regulation of RNA processing by PARPs occurs at nearly all of the key steps. RNA regulation is an exciting area of PARP biology, but much work remains to be performed.

Acknowledgements This work was supported by grants from the National Natural Science Foundation of China (Grant numbers: 31371293 to XB and 31801182 to YK) and the Natural Science Foundation of Jilin Province (No. 20190103068JH to YK and $20180101236 J C$ to XB). The project was funded by the China Postdoctoral Science Foundation (No. 2018M630313 and 2018T110239 to $\mathrm{YK})$.

Compliance with ethical standards

Conflict of interest The authors declare no conflict of interest.

Open Access This article is distributed under the terms of the Creative Commons Attribution 4.0 International License (http://creativeco mmons.org/licenses/by/4.0/), which permits unrestricted use, distribution, and reproduction in any medium, provided you give appropriate credit to the original author(s) and the source, provide a link to the Creative Commons license, and indicate if changes were made.

\section{References}

1. Anderson P (2010) Post-transcriptional regulons coordinate the initiation and resolution of inflammation. Nat Rev Immunol 10(1):24-35

2. Brennan CM, Steitz JA (2001) HuR and mRNA stability. Cell Mol Life Sci 58(2):266-277

3. Keene JD (2007) RNA regulons: coordination of post-transcriptional events. Nat Rev Genet 8(7):533-543
4. Ji Y, Tulin AV (2013) Post-transcriptional regulation by poly(ADP-ribosyl)ation of the RNA-binding proteins. Int J Mol Sci 14(8):16168-16183

5. Lukong KE, Chang KW, Khandjian EW, Richard S (2008) RNA-binding proteins in human genetic disease. Trends Genet 24(8):416-425

6. Ke Y, Han Y, Guo X, Wen J, Wang K, Jiang X, Tian X, Ba X, Boldogh I, Zeng X (2017) Erratum: PARP1 promotes gene expression at the post-transcriptional level by modulating the RNA-binding protein HuR. Nat Commun 8:15191

7. Schreiber V, Dantzer F, Ame JC, de Murcia G (2006) Poly(ADP-ribose): novel functions for an old molecule. Nat Rev Mol Cell Biol 7(7):517-528

8. Krishnakumar R, Kraus WL (2010) The PARP side of the nucleus: molecular actions, physiological outcomes, and clinical targets. Mol Cell 39(1):8-24

9. Gibson BA, Kraus WL (2012) New insights into the molecular and cellular functions of poly(ADP-ribose) and PARPs. Nat Rev Mol Cell Biol 13(7):411-424

10. Bock FJ, Todorova TT, Chang P (2015) RNA regulation by poly(ADP-Ribose) polymerases. Mol Cell 58(6):959-969

11. Teloni F, Altmeyer M (2016) Readers of poly(ADPribose): designed to be fit for purpose. Nucleic Acids Res 44(3):993-1006

12. Ke Y, Wang K, Xu H, Wang C, Zhang J, Zeng X, Wang R, Boldogh I, Ba X (2018) The establishment of methods for free PAR generation and PAR reader detection. Mol Cell Probes 39:57-60

13. Wang R, Li C, Qiao P, Xue Y, Zheng X, Chen H, Zeng X, Liu W, Boldogh I, Ba X (2018) OGG1-initiated base excision repair exacerbates oxidative stress-induced parthanatos. Cell Death Dis 9(6):628

14. Wang Y, Kim NS, Haince JF, Kang HC, David KK, Andrabi SA, Poirier GG, Dawson VL, Dawson TM (2011) Poly(ADPribose) (PAR) binding to apoptosis-inducing factor is critical for PAR polymerase-1-dependent cell death (parthanatos). Sci Signal 4(167):ra20

15. Fahrer J, Popp O, Malanga M, Beneke S, Markovitz DM, Ferrando-May E, Burkle A, Kappes F (2010) High-affinity interaction of poly(ADP-ribose) and the human DEK oncoprotein depends upon chain length. Biochemistry 49(33):7119-7130

16. Ba X, Gupta S, Davidson M, Garg NJ (2010) Trypanosoma cruzi induces the reactive oxygen species-PARP-1-RelA 
pathway for up-regulation of cytokine expression in cardiomyocytes. J Biol Chem 285(15):11596-11606

17. Wright RH, Lioutas A, Le Dily F, Soronellas D, Pohl A, Bonet J, Nacht AS, Samino S, Font-Mateu J, Vicent GP, Wierer M, Trabado MA, Schelhorn C, Carolis C, Macias MJ, Yanes O, Oliva B, Beato M (2016) ADP-ribose-derived nuclear ATP synthesis by NUDIX5 is required for chromatin remodeling. Science 352(6290):1221-1225

18. Fischbach A, Kruger A, Hampp S, Assmann G, Rank L, Hufnagel M, Stockl MT, Fischer JMF, Veith S, Rossatti P, Ganz M, Ferrando-May E, Hartwig A, Hauser K, Wiesmuller L, Burkle A, Mangerich A (2018) The C-terminal domain of p53 orchestrates the interplay between non-covalent and covalent poly(ADP-ribosyl)ation of $\mathrm{p} 53$ by PARP1. Nucleic Acids Res 46(2):804-822

19. Min W, Bruhn C, Grigaravicius P, Zhou ZW, Li F, Kruger A, Siddeek B, Greulich KO, Popp O, Meisezahl C, Calkhoven CF, Burkle A, Xu X, Wang ZQ (2013) Poly(ADP-ribose) binding to Chk1 at stalled replication forks is required for S-phase checkpoint activation. Nat Commun 4:2993

20. Krietsch J, Caron MC, Gagne JP, Ethier C, Vignard J, Vincent M, Rouleau M, Hendzel MJ, Poirier GG, Masson JY (2012) PARP activation regulates the RNA-binding protein NONO in the DNA damage response to DNA double-strand breaks. Nucleic Acids Res 40(20):10287-10301

21. Ikejima M, Noguchi S, Yamashita R, Ogura T, Sugimura T, Gill DM, Miwa M (1990) The zinc fingers of human poly(ADPribose) polymerase are differentially required for the recognition of DNA breaks and nicks and the consequent enzyme activation. Other structures recognize intact DNA. J Biol Chem 265(35):21907-21913

22. Semighini CP, Savoldi M, Goldman GH, Harris SD (2006) Functional characterization of the putative Aspergillus nidulans poly(ADP-ribose) polymerase homolog PrpA. Genetics 173(1):87-98

23. Mangerich A, Burkle A (2011) How to kill tumor cells with inhibitors of poly(ADP-ribosyl)ation. Int J Cancer 128(2):251-265

24. Benjamin RC, Gill DM (1980) Poly(ADP-ribose) synthesis in vitro programmed by damaged DNA. A comparison of DNA molecules containing different types of strand breaks. J Biol Chem 255(21):10502-10508

25. Alvarez-Gonzalez R, Althaus FR (1989) Poly(ADP-ribose) catabolism in mammalian cells exposed to DNA-damaging agents. Mutat Res 218(2):67-74

26. Luo X, Kraus WL (2012) On PAR with PARP: cellular stress signaling through poly(ADP-ribose) and PARP-1. Genes Dev 26(5):417-432

27. Liu L, Ke Y, Jiang X, He F, Pan L, Xu L, Zeng X, Ba X (2012) Lipopolysaccharide activates ERK-PARP-1-RelA pathway and promotes nuclear factor-kappaB transcription in murine macrophages. Hum Immunol 73(5):439-447

28. Altmeyer M, Hottiger MO (2009) Poly(ADP-ribose) polymerase 1 at the crossroad of metabolic stress and inflammation in aging. Aging (Albany NY) 1(5):458-469

29. Ba X, Garg NJ (2011) Signaling mechanism of poly(ADP-ribose) polymerase-1 (PARP-1) in inflammatory diseases. Am J Pathol 178(3):946-955

30. Kraus WL, Lis JT (2003) PARP goes transcription. Cell 113(6):677-683

31. Gupte R, Liu Z, Kraus WL (2017) PARPs and ADP-ribosylation: recent advances linking molecular functions to biological outcomes. Genes Dev 31(2):101-126

32. Posavec Marjanovic M, Crawford K, Ahel I (2017) PARP, transcription and chromatin modeling. Semin Cell Dev Biol 63:102-113
33. Kraus WL, Hottiger MO (2013) PARP-1 and gene regulation: progress and puzzles. Mol Aspects Med 34(6):1109-1123

34. Huletsky A, de Murcia G, Muller S, Hengartner M, Menard L, Lamarre D, Poirier GG (1989) The effect of poly(ADPribosyl)ation on native and H1-depleted chromatin. A role of poly(ADP-ribosyl)ation on core nucleosome structure. J Biol Chem 264(15):8878-8886

35. Kim MY, Mauro S, Gevry N, Lis JT, Kraus WL (2004) NAD +-dependent modulation of chromatin structure and transcription by nucleosome binding properties of PARP-1. Cell 119(6):803-814

36. Krishnakumar R, Gamble MJ, Frizzell KM, Berrocal JG, Kininis M, Kraus WL (2008) Reciprocal binding of PARP-1 and histone $\mathrm{H} 1$ at promoters specifies transcriptional outcomes. Science 319(5864):819-821

37. Krishnakumar R, Kraus WL (2010) PARP-1 regulates chromatin structure and transcription through a KDM5B-dependent pathway. Mol Cell 39(5):736-749

38. Hau AC, Grebbin BM, Agoston Z, Anders-Maurer M, Muller T, Gross A, Kolb J, Langer JD, Doring C, Schulte D (2017) MEIS homeodomain proteins facilitate PARP1/ARTD1-mediated eviction of histone H1. J Cell Biol 216(9):2715-2729

39. Ong CT, Van Bortle K, Ramos E, Corces VG (2013) Poly(ADPribosyl)ation regulates insulator function and intrachromosomal interactions in Drosophila. Cell 155(1):148-159

40. Farrar D, Rai S, Chernukhin I, Jagodic M, Ito Y, Yammine S, Ohlsson R, Murrell A, Klenova E (2010) Mutational analysis of the poly(ADP-ribosyl)ation sites of the transcription factor CTCF provides an insight into the mechanism of its regulation by poly(ADP-ribosyl)ation. Mol Cell Biol 30(5):1199-1216

41. Zhao H, Sifakis EG, Sumida N, Millan-Arino L, Scholz BA, Svensson JP, Chen X, Ronnegren AL, Mallet de Lima CD, Varnoosfaderani FS, Shi C, Loseva O, Yammine S, Israelsson M, Rathje LS, Nemeti B, Fredlund E, Helleday T, Imreh MP, Gondor A (2015) PARP1- and CTCF-mediated interactions between active and repressed chromatin at the lamina promote oscillating transcription. Mol Cell 59(6):984-997

42. Lupey-Green LN, Caruso LB, Madzo J, Martin KA, Tan Y, Hulse M, Tempera I (2018) PARP1 stabilizes CTCF binding and chromatin structure to maintain epstein-barr virus latency type. $\mathrm{J}$ Virol 92(18):e00755-18

43. Chau CM, Zhang XY, McMahon SB, Lieberman PM (2006) Regulation of Epstein-Barr virus latency type by the chromatin boundary factor CTCF. J Virol 80(12):5723-5732

44. Kraus WL (2008) Transcriptional control by PARP-1: chromatin modulation, enhancer-binding, coregulation, and insulation. Curr Opin Cell Biol 20(3):294-302

45. Ghosh G, Wang VY, Huang DB, Fusco A (2012) NF-kappaB regulation: lessons from structures. Immunol Rev 246(1):36-58

46. Hassa PO, Buerki C, Lombardi C, Imhof R, Hottiger MO (2003) Transcriptional coactivation of nuclear factor-kappaB-dependent gene expression by $\mathrm{p} 300$ is regulated by poly(ADP)-ribose polymerase-1. J Biol Chem 278(46):45145-45153

47. Hassa PO, Haenni SS, Buerki C, Meier NI, Lane WS, Owen $\mathrm{H}$, Gersbach M, Imhof R, Hottiger MO (2005) Acetylation of poly(ADP-ribose) polymerase-1 by p300/CREB-binding protein regulates coactivation of NF-kappaB-dependent transcription. J Biol Chem 280(49):40450-40464

48. Zerfaoui M, Errami Y, Naura AS, Suzuki Y, Kim H, Ju J, Liu T, Hans CP, Kim JG, Abd Elmageed ZY, Koochekpour S, Catling A, Boulares AH (2010) Poly(ADP-ribose) polymerase-1 is a determining factor in Crm1-mediated nuclear export and retention of p65 NF-kappa B upon TLR4 stimulation. J Immunol 185(3):1894-1902

49. Kanai M, Hanashiro K, Kim SH, Hanai S, Boulares AH, Miwa M, Fukasawa K (2007) Inhibition of Crm1-p53 interaction and 
nuclear export of p53 by poly(ADP-ribosyl)ation. Nat Cell Biol 9(10):1175-1183

50. Fahrer J, Kranaster R, Altmeyer M, Marx A, Burkle A (2007) Quantitative analysis of the binding affinity of poly(ADP-ribose) to specific binding proteins as a function of chain length. Nucleic Acids Res 35(21):e143

51. Luo X, Ryu KW, Kim DS, Nandu T, Medina CJ, Gupte R, Gibson BA, Soccio RE, Yu Y, Gupta RK, Kraus WL (2017) PARP-1 controls the adipogenic transcriptional program by PARylating $\mathrm{C} / \mathrm{EBPbeta}$ and modulating its transcriptional activity. Mol Cell 65(2):260-271

52. Venables JP, Tazi J, Juge F (2012) Regulated functional alternative splicing in Drosophila. Nucleic Acids Res 40(1):1-10

53. Matveeva E, Maiorano J, Zhang Q, Eteleeb AM, Convertini P, Chen J, Infantino V, Stamm S, Wang J, Rouchka EC, FondufeMittendorf YN (2016) Involvement of PARP1 in the regulation of alternative splicing. Cell Discov 2:15046

54. Pan Q, Shai O, Lee LJ, Frey BJ, Blencowe BJ (2008) Deep surveying of alternative splicing complexity in the human transcriptome by high-throughput sequencing. Nat Genet 40(12):1413-1415

55. Wang ET, Sandberg R, Luo S, Khrebtukova I, Zhang L, Mayr C, Kingsmore SF, Schroth GP, Burge CB (2008) Alternative isoform regulation in human tissue transcriptomes. Nature 456(7221):470-476

56. Allemand E, Batsche E, Muchardt C (2008) Splicing, transcription, and chromatin: a menage a trois. Curr Opin Genet Dev 18(2):145-151

57. Melikishvili M, Chariker JH, Rouchka EC, Fondufe-Mittendorf YN (2017) Transcriptome-wide identification of the RNA-binding landscape of the chromatin-associated protein PARP1 reveals functions in RNA biogenesis. Cell Discov 3:17043

58. Matveeva EA, Al-Tinawi QMH, Rouchka EC, Fondufe-Mittendorf YN (2019) Coupling of PARP1-mediated chromatin structural changes to transcriptional RNA polymerase II elongation and cotranscriptional splicing. Epigenetics Chromatin 12(1):15

59. Gagne JP, Hunter JM, Labrecque B, Chabot B, Poirier GG (2003) A proteomic approach to the identification of heterogeneous nuclear ribonucleoproteins as a new family of poly(ADP-ribose)binding proteins. Biochem J 371(Pt 2):331-340

60. Chaudhury A, Chander P, Howe PH (2010) Heterogeneous nuclear ribonucleoproteins (hnRNPs) in cellular processes: focus on hnRNP E1's multifunctional regulatory roles. RNA 16(8):1449-1462

61. Ji Y, Tulin AV (2009) Poly(ADP-ribosyl)ation of heterogeneous nuclear ribonucleoproteins modulates splicing. Nucleic Acids Res 37(11):3501-3513

62. Malanga M, Czubaty A, Girstun A, Staron K, Althaus FR (2008) Poly(ADP-ribose) binds to the splicing factor ASF/SF2 and regulates its phosphorylation by DNA topoisomerase I. J Biol Chem 283(29):19991-19998

63. Rossi F, Labourier E, Forne T, Divita G, Derancourt J, Riou JF, Antoine E, Cathala G, Brunel C, Tazi J (1996) Specific phosphorylation of SR proteins by mammalian DNA topoisomerase I. Nature 381(6577):80-82

64. Stamm S (2008) Regulation of alternative splicing by reversible protein phosphorylation. J Biol Chem 283(3):1223-1227

65. Cremer T, Cremer C (2001) Chromosome territories, nuclear architecture and gene regulation in mammalian cells. Nat Rev Genet 2(4):292-301

66. Ogg SC, Lamond AI (2002) Cajal bodies and coilin-moving towards function. J Cell Biol 159(1):17-21

67. Kotova E, Jarnik M, Tulin AV (2009) Poly (ADP-ribose) polymerase 1 is required for protein localization to Cajal body. PLoS Genet 5(2):e1000387
68. Schoenberg DR, Maquat LE (2012) Regulation of cytoplasmic mRNA decay. Nat Rev Genet 13(4):246-259

69. Shi Y, Di Giammartino DC, Taylor D, Sarkeshik A, Rice WJ, Yates JR 3rd, Frank J, Manley JL (2009) Molecular architecture of the human pre-mRNA 3' processing complex. Mol Cell 33(3):365-376

70. Di Giammartino DC, Shi Y, Manley JL (2013) PARP1 represses PAP and inhibits polyadenylation during heat shock. Mol Cell 49(1):7-17

71. Edmonds M (2002) A history of poly A sequences: from formation to factors to function. Prog Nucleic Acid Res Mol Biol 71:285-389

72. Bjork P, Wieslander L (2017) Integration of mRNP formation and export. Cell Mol Life Sci 74(16):2875-2897

73. Williams T, Ngo LH, Wickramasinghe VO (2018) Nuclear export of RNA: different sizes, shapes and functions. Semin Cell Dev Biol 75:70-77

74. Gallouzi IE, Steitz JA (2001) Delineation of mRNA export pathways by the use of cell-permeable peptides. Science 294(5548):1895-1901

75. Brennan CM, Gallouzi IE, Steitz JA (2000) Protein ligands to HuR modulate its interaction with target mRNAs in vivo. J Cell Biol 151(1):1-14

76. Fries B, Heukeshoven J, Hauber I, Gruttner C, Stocking C, Kehlenbach RH, Hauber J, Chemnitz J (2007) Analysis of nucleocytoplasmic trafficking of the HuR ligand APRIL and its influence on CD83 expression. J Biol Chem 282(7):4504-4515

77. Noh JH, Kim KM, Abdelmohsen K, Yoon JH, Panda AC, Munk R, Kim J, Curtis J, Moad CA, Wohler CM, Indig FE, de Paula W, Dudekula DB, De S, Piao Y, Yang X, Martindale JL, de Cabo R, Gorospe M (2016) HuR and GRSF1 modulate the nuclear export and mitochondrial localization of the lncRNA RMRP. Genes Dev 30(10):1224-1239

78. Chang DD, Clayton DA (1987) A mammalian mitochondrial RNA processing activity contains nucleus-encoded RNA. Science 235(4793):1178-1184

79. Chang DD, Clayton DA (1989) Mouse RNAase MRP RNA is encoded by a nuclear gene and contains a decamer sequence complementary to a conserved region of mitochondrial RNA substrate. Cell 56(1):131-139

80. Battaglia-Hsu SF, Ghemrawi R, Coelho D, Dreumont N, Mosca P, Hergalant S, Gauchotte G, Sequeira JM, Ndiongue M, Houlgatte R, Alberto JM, Umoret R, Robert A, Paoli J, Jung M, Quadros EV, Gueant JL (2018) Inherited disorders of cobalamin metabolism disrupt nucleocytoplasmic transport of mRNA through impaired methylation/phosphorylation of ELAVL1/HuR. Nucleic Acids Res 46(15):7844-7857

81. Luster AD, Leder P (1993) IP-10, a-C-X-C- chemokine, elicits a potent thymus-dependent antitumor response in vivo. J Exp Med 178(3):1057-1065

82. Feldman ED, Weinreich DM, Carroll NM, Burness ML, Feldman AL, Turner E, Xu H, Alexander HR Jr (2006) Interferon gammainducible protein 10 selectively inhibits proliferation and induces apoptosis in endothelial cells. Ann Surg Oncol 13(1):125-133

83. Galbis-Martinez M, Saenz L, Ramirez P, Parrilla P, Yelamos J (2010) Poly(ADP-ribose) polymerase-1 modulates interferongamma-inducible protein (IP)-10 expression in murine embryonic fibroblasts by stabilizing IP-10 mRNA. Mol Immunol 47(7-8):1492-1499

84. Bakheet T, Williams BR, Khabar KS (2003) ARED 2.0: an update of AU-rich element mRNA database. Nucleic Acids Res 31(1):421-423

85. Ma WJ, Cheng S, Campbell C, Wright A, Furneaux H (1996) Cloning and characterization of HuR, a ubiquitously expressed Elav-like protein. J Biol Chem 271(14):8144-8151 
86. Fan XC, Steitz JA (1998) HNS, a nuclear-cytoplasmic shuttling sequence in HuR. Proc Natl Acad Sci USA 95(26):15293-15298

87. Hinman MN, Lou H (2008) Diverse molecular functions of $\mathrm{Hu}$ proteins. Cell Mol Life Sci 65(20):3168-3181

88. Kim HH, Yang X, Kuwano Y, Gorospe M (2008) Modification at $\mathrm{HuR}(\mathrm{S} 242)$ alters HuR localization and proliferative influence. Cell Cycle 7(21):3371-3377

89. Kim HH, Abdelmohsen K, Lal A, Pullmann R Jr, Yang X, Galban S, Srikantan S, Martindale JL, Blethrow J, Shokat KM, Gorospe M (2008) Nuclear HuR accumulation through phosphorylation by Cdk1. Genes Dev 22(13):1804-1815

90. Lucchesi C, Sheikh MS, Huang Y (2016) Negative regulation of RNA-binding protein HuR by tumor-suppressor ECRG2. Oncogene 35(20): 2565-2573

91. Li H, Park S, Kilburn B, Jelinek MA, Henschen-Edman A, Aswad DW, Stallcup MR, Laird-Offringa IA (2002) Lipopolysaccharide-induced methylation of HuR, an mRNA-stabilizing protein, by CARM1. Coactivator-associated arginine methyltransferase. J Biol Chem 277(47):44623-44630

92. Grammatikakis I, Abdelmohsen K, Gorospe M (2017) Posttranslational control of HuR function. Wiley Interdiscip Rev RNA 8:e1372

93. Chand SN, Zarei M, Schiewer MJ, Kamath AR, Romeo C, Lal S, Cozzitorto JA, Nevler A, Scolaro L, Londin E, Jiang W, MeisnerKober N, Pishvaian MJ, Knudsen KE, Yeo CJ, Pascal JM, Winter JM, Brody JR (2017) Posttranscriptional regulation of PARG mRNA by HuR facilitates DNA repair and resistance to PARP inhibitors. Cancer Res 77(18):5011-5025

94. Leung A, Todorova T, Ando Y, Chang P (2012) Poly(ADPribose) regulates post-transcriptional gene regulation in the cytoplasm. RNA Biol 9(5):542-548

95. Bai P (2015) Biology of poly(ADP-Ribose) polymerases: the factotums of cell maintenance. Mol Cell 58(6):947-958

96. Bock FJ, Chang P (2016) New directions in poly(ADP-ribose) polymerase biology. FEBS J 283(22):4017-4031

97. Kayali F, Montie HL, Rafols JA, DeGracia DJ (2005) Prolonged translation arrest in reperfused hippocampal cornu Ammonis 1 is mediated by stress granules. Neuroscience 134(4):1223-1245

98. Leung AK, Vyas S, Rood JE, Bhutkar A, Sharp PA, Chang P (2011) Poly(ADP-ribose) regulates stress responses and microRNA activity in the cytoplasm. Mol Cell 42(4):489-499

99. Welsby I, Hutin D, Gueydan C, Kruys V, Rongvaux A, Leo O (2014) PARP12, an interferon-stimulated gene involved in the control of protein translation and inflammation. J Biol Chem 289(38):26642-26657

100. Catara G, Grimaldi G, Schembri L, Spano D, Turacchio G, Lo Monte M, Beccari AR, Valente C, Corda D (2017) PARP1produced poly-ADP-ribose causes the PARP12 translocation to stress granules and impairment of Golgi complex functions. Sci Rep 7(1):14035

101. Todorova T, Bock FJ, Chang P (2015) Poly(ADP-ribose) polymerase-13 and RNA regulation in immunity and cancer. Trends Mol Med 21(6):373-384

102. Todorova T, Bock FJ, Chang P (2014) PARP13 regulates cellular mRNA post-transcriptionally and functions as a pro-apoptotic factor by destabilizing TRAILR4 transcript. Nat Commun 5:5362

103. Cho SH, Goenka S, Henttinen T, Gudapati P, Reinikainen A, Eischen CM, Lahesmaa R, Boothby M (2009) PARP-14, a member of the B aggressive lymphoma family, transduces survival signals in primary B cells. Blood 113(11):2416-2425

104. Cho SH, Ahn AK, Bhargava P, Lee CH, Eischen CM, McGuinness O, Boothby M (2011) Glycolytic rate and lymphomagenesis depend on PARP14, an ADP ribosyltransferase of the B aggressive lymphoma (BAL) family. Proc Natl Acad Sci USA 108(38):15972-15977
105. Iqbal MB, Johns M, Cao J, Liu Y, Yu SC, Hyde GD, Laffan MA, Marchese FP, Cho SH, Clark AR, Gavins FN, Woollard KJ, Blackshear PJ, Mackman N, Dean JL, Boothby M, Haskard DO (2014) PARP-14 combines with tristetraprolin in the selective posttranscriptional control of macrophage tissue factor expression. Blood 124(24):3646-3655

106. Hanahan D, Weinberg RA (2011) Hallmarks of cancer: the next generation. Cell 144(5):646-674

107. Medzhitov R (2008) Origin and physiological roles of inflammation. Nature 454(7203):428-435

108. Sethi GS, Dharwal V, Naura AS (2017) Poly(ADP-Ribose) polymerase-1 in7 lung inflammatory disorders: a review. Front Immunol 8:1172

109. Hassa PO, Hottiger MO (2002) The functional role of poly(ADPribose)polymerase 1 as novel coactivator of NF-kappaB in inflammatory disorders. Cell Mol Life Sci 59(9):1534-1553

110. Weaver AN, Yang ES (2013) Beyond DNA repair: additional functions of PARP-1 in cancer. Front Oncol 3:290

111. Mishra M, Kowluru RA (2017) Role of PARP-1 as a novel transcriptional regulator of MMP-9 in diabetic retinopathy. Biochim Biophys Acta Mol Basis Dis 1863 7:1761-1769

112. Kunze FA, Hottiger MO (2019) Regulating immunity via ADPribosylation: therapeutic implications and beyond. Trends Immunol 40(2):159-173

113. Haddad M, Rhinn H, Bloquel C, Coqueran B, Szabo C, Plotkine M, Scherman D, Margaill I (2006) Anti-inflammatory effects of $\mathrm{PJ} 34$, a poly(ADP-ribose) polymerase inhibitor, in transient focal cerebral ischemia in mice. Br J Pharmacol 149(1):23-30

114. Jijon HB, Churchill T, Malfair D, Wessler A, Jewell LD, Parsons HG, Madsen KL (2000) Inhibition of poly(ADP-ribose) polymerase attenuates inflammation in a model of chronic colitis. Am J Physiol Gastrointest Liver Physiol 279(3):G641-G651

115. Korkmaz A, Kurt B, Yildirim I, Basal S, Topal T, Sadir S, Oter S (2008) Effects of poly(ADP-ribose) polymerase inhibition in bladder damage caused by cyclophosphamide in rats. Exp Biol Med (Maywood) 233(3):338-343

116. Henning RJ, Bourgeois M, Harbison RD (2018) Poly(ADPribose) polymerase (PARP) and PARP inhibitors: mechanisms of action and role in cardiovascular disorders. Cardiovasc Toxicol 18(6):493-506

117. Olabisi OA, Soto-Nieves N, Nieves E, Yang TT, Yang X, Yu RY, Suk HY, Macian F, Chow CW (2008) Regulation of transcription factor NFAT by ADP-ribosylation. Mol Cell Biol 28(9):2860-2871

118. Zingarelli B, Hake PW, Burroughs TJ, Piraino G, O'Connor M, Denenberg A (2004) Activator protein-1 signalling pathway and apoptosis are modulated by poly(ADP-ribose) polymerase- 1 in experimental colitis. Immunology 113(4):509-517

119. Ditsworth D, Zong WX, Thompson CB (2007) Activation of poly(ADP)-ribose polymerase (PARP-1) induces release of the pro-inflammatory mediator HMGB 1 from the nucleus. J Biol Chem 282(24):17845-17854

120. Rodriguez MI, Gonzalez-Flores A, Dantzer F, Collard J, de Herreros AG, Oliver FJ (2011) Poly(ADP-ribose)-dependent regulation of Snail1 protein stability. Oncogene 30(42):4365-4372

121. Lu H, Wang X, Li T, Urvalek AM, Yu L, Li J, Zhu J, Lin Q, Peng $X$, Zhao J (2011) Identification of poly (ADP-ribose) polymerase-1 (PARP-1) as a novel Kruppel-like factor 8-interacting and -regulating protein. J Biol Chem 286(23):20335-20344

122. Datta R, Naura AS, Zerfaoui M, Errami Y, Oumouna M, Kim H, Ju J, Ronchi VP, Haas AL, Boulares AH (2011) PARP-1 deficiency blocks IL-5 expression through calpain-dependent degradation of STAT-6 in a murine asthma model. Allergy 66(7):853-861

123. Kiefmann R, Heckel K, Doerger M, Schenkat S, Kupatt C, Stoeckelhuber M, Wesierska-Gadek J, Goetz AE (2004) Role of 
PARP on iNOS pathway during endotoxin-induced acute lung injury. Intensive Care Med 30(7):1421-1431

124. Sofola OA, Jin P, Qin Y, Duan R, Liu H, de Haro M, Nelson DL, Botas J (2007) RNA-binding proteins hnRNP A2/B1 and CUGBP1 suppress fragile X CGG premutation repeat-induced neurodegeneration in a Drosophila model of FXTAS. Neuron 55(4):565-571

125. Leger K, Bar D, Savic N, Santoro R, Hottiger MO (2014) ARTD2 activity is stimulated by RNA. Nucleic Acids Res 42(8):5072-5082

126. Kamboj A, Lu P, Cossoy MB, Stobart JL, Dolhun BA, Kauppinen TM, de Murcia G, Anderson CM (2013) Poly(ADP-ribose) polymerase 2 contributes to neuroinflammation and neurological dysfunction in mouse experimental autoimmune encephalomyelitis. J Neuroinflammation 10:49

127. Verheugd P, Forst AH, Milke L, Herzog N, Feijs KL, Kremmer E, Kleine H, Luscher B (2013) Regulation of NF-kappaB signalling by the mono-ADP-ribosyltransferase ARTD10. Nat Commun 4:1683
128. Mehrotra P, Hollenbeck A, Riley JP, Li F, Patel RJ, Akhtar N, Goenka S (2013) Poly (ADP-ribose) polymerase 14 and its enzyme activity regulates $\mathrm{T}(\mathrm{H}) 2$ differentiation and allergic airway disease. J Allergy Clin Immunol 131(2):521-531 (e521-512)

129. Iansante V, Choy PM, Fung SW, Liu Y, Chai JG, Dyson J, Del Rio A, D'Santos C, Williams R, Chokshi S, Anders RA, Bubici C, Papa S (2015) PARP14 promotes the Warburg effect in hepatocellular carcinoma by inhibiting JNK1-dependent PKM2 phosphorylation and activation. Nat Commun 6:7882

Publisher's Note Springer Nature remains neutral with regard to jurisdictional claims in published maps and institutional affiliations. 